\title{
Biblical narratives, messianic hopes and religious radicalism: Jewish fundamentalism in our time
}

Yaakov Ariel

The paper examines the contemporary scene of Jewish fundamentalism, focusing on its two major wings: the separatist Ultra-Orthodox, and the more culturally accommodating but politically radical Zionist Orthodox Settlers and would-be Temple Builders. Both those segments of Judaism have been demographically and institutionally on the rise in the last generation and have made their impact on the political scene, changing the character and image of Judaism as a whole. The essay comes to offer an historical and sociological context to the formation, development and growth in numbers and importance of the two camps. It points to the diversity within the two camps and relates to major institutions, leaders and theological concepts. It also examines the meaning of the term fundamentalism in late modern Judaism and points to the fact that while there are obvious differences between the Ultra and the Zionist Orthodox, there are also striking similarities. These demonstrate themselves, among other features, in the centrality of scriptural narratives to the two groups, including the idea of holding a special place in God's plans for humanity, and the idea of the imminent or eventual arrival of the messianic times.

A graduate of the Hebrew University and the University of Chicago, Yaakov Ariel's research focuses on messianic, hybrid, or radical movements in contemporary Judaism and Christianity, as well as on Christian-Jewish relations in the Modern Era. He has published numerous articles as well as a number of books on these topics. His book, Evangelizing the Chosen People, won the Outler Prize of the American Society of Church History. His latest book, An Unusual Relationship: Evangelical Christians and Jews, was published by New York University Press in 2013. Ariel teaches at the University of North Carolina at Chapel Hill, where he is currently co-director of the Center for Jewish Studies, and director of the Minor in the Study of Christianity and Culture.

\section{Introduction}

Ample media coverage, in recent years, has focused attention on the separatist Ultra-Orthodox communities, as well as on the more culturally accommodating but politically radical groups of Jewish Settlers and would be Temple-Builders in Israel. Those segments of Judaism have been on the rise in the last generation, both demographically and institutionally. As the recent news from Israel demonstrate these fundamentalist groups are currently prominent on the political scene, affecting national policies. The declarations and actions of some members 
of the groups in relation to Israeli settlements and the Temple Mount, or Haram al-Sharif, have played a part in the escalating mistrust between Moslems and Jews in Israel, the territories it occupies, and beyond.

Few, however, are aware of the history and development of the Jewish fundamentalist movements and the varied characteristics of the many groups that make up these camps. This paper aims to place the movements within the larger social, cultural and religious contexts in which they have evolved and to which they have reacted. The paper will point to two major camps of contemporary Jewish fundamentalists that differ from each other in their theologies, communal structures, life styles, and political choices. It will also point to mutual influences, common characteristics and shared perceptions.

Jewish religious fundamentalists take affirmative stands, upholding and strengthening tradition in face of other options in Jewish culture. They insist on the validity and authority of the Jewish sacred scriptures, see special merits in studying the texts, and are highly protective of the narratives the texts offer. Both groups are messianically-oriented, but while the Zionist-Orthodox believes in taking an active role in history, the Ultra-Orthodox have often objected to such attempts. ${ }^{1}$ While the Ultra-Orthodox take their model from the alter heim, Eastern European Jewish society before Communism, Nazism and emigration to western countries or Israel brought it to an end, Zionist Orthodox groups have come instead to promote the Land of Israel as a focal point of their political vision. $^{2}$

\section{Fundamentalist Ultra-Orthodoxy}

The largest of the religious fundamentalist movements within contemporary Judaism is Ultra-Orthodoxy. ${ }^{3}$ This diverse fundamentalist movement started in Central Europe, in the nineteenth century, in reaction to movements of acculturation and liberalization. ${ }^{4}$ It spread to Jewish communities in other parts of the world, changing and evolving in response to new environments and challenges.

Until the turn of the nineteenth century, the term "orthodox" was rarely used to define Jews, but matters changed in the early nineteenth century when leaders of more militant forms of reactive traditional Judaism appeared on the scene, declared themselves "orthodox" in contrast to what they considered to be the erring reformers. Until such alternatives appeared within Jewish society, Jews could move away from the faith by converting to another religion, but they could not pick and choose on an individual basis what elements of their tradition they

1 Ravitzky 1996, chapter 4.

2 On the ethos of Ultra-Orthodox society, see Friedman 1991.

3 Ibid.

4 Katz 1973. 
wished to observe. Now, such choices became possible. In Western and Central Europe, as well as in the New World, many Jews liberalized, easing up or giving up completely on daily observance of their tradition. A number of rabbis and laypersons made deliberate efforts to bring Judaism to par with the cultural norms of urban European societies. ${ }^{5}$ Those deciding to uphold tradition considered the liberal reformers to be misguided, if not outright traitorous. They set out to create a stern uncompromising version of traditional Judaism that would not walk the line of compromise and eventual demise of the tradition.

Ultra-Orthodoxy has not been a self-designation. Most members of this camp prefer instead terms that express their understanding of themselves as the utmost loyal followers of the Jewish faith, using at times the terms "Torah Camp", or Haredim, Eager to Follow God, to describe their ideological commitment and cultural environment.

Michael Silber has pointed out that the Ultra-Orthodox reacted not only to the rise of reform or secular forms of Jewish life, but also to the appearance of acculturated forms of Orthodoxy whose holders had wished to make observant forms of Judaism compatible with modern life. ${ }^{6}$ The Ultra-Orthodox have claimed that even minor attempts at acculturation or reform could be the beginning of a decline in commitment and deterioration in the standards of observing the faith that end with the complete disintegration of the tradition. The first Ultra-Orthodox leaders lashed out at early Orthodox thinkers, such as Moses Mendelssohn, and even at Samson Raphael Hirsch and Azriel Hildesheimer, who were, in fact, founders of a more firm form of Orthodox Judaism and militated against reforms of the faith. ${ }^{7}$

If Moses Mendelssohn was the thinker most associated with the beginning of a moderate, acculturated form of Jewish Orthodoxy, Moses Sofer (Schreiber) of Pressburg (Bratislava), known as the Hatam Sofer (1762-1839), was the early founder of Ultra-Orthodoxy. Spiritual leader of the utmost Eastern urban center of the Habsburg Empire, Sofer established a yeshiva that became a bastion of anti-modernism in Central and Eastern Europe. The Hatam Sofer pun on a Talmudic ruling, "Kol hadash asur min ha Torah", the Torah forbids everything that is new, became a battle cry of Ultra-Orthodoxy. It has reflected the dialectics of the new movement, which has come about within the context of modernity yet carried a banner of opposition to modernism and acculturation, and while thoroughly opposing reforms, made profound theological and practical changes in the tradition. It was perhaps not surprising that the Hatam Sofer held expectations for the imminent arrival of the Messiah to usher in a global righteous age and brings about the redemption of Israel. In contrast to the newly emerging circles of liberal

\footnotetext{
5 Mayer 1995.

6 Silber 1992.

7 Kahana 2015. On Hirsch, Hildsheimer and the rise of German Jewish neo-Orthodoxy, see Breuer 1992.
} 
Jews who adopted at that time progressive millennial views and hoped to build the Kingdom of God on Earth through education, the spreading of the values of the Enlightenment, technological advancement, and political reforms, the Hatam Sofer believed that the messianic era would not be ushered in through human efforts, but rather through divine intervention and busied himself in trying to calculate the exact date of its arrival. In that regard there are some striking similarities between the ideologies and attitudes of Ultra-Orthodoxy and those of fundamentalist movements that have come about in other religious traditions in the late modern era. ${ }^{8}$ Like other such movements, Ultra-Orthodoxy should be understood as a reactionary development in the history of Judaism. If in previous generations, there was more leeway for rabbis to issue accommodating rulings, and for laypersons to balance the demands of day to day life with those of tradition and the halakha, now regulations and standards have become more stringent and greater emphasize put on separation from outside cultures including other groups of Jews.

In their declared ideology as well as in their own minds, the Ultra-Orthodox created nothing new. They have seen themselves as merely preserving the customs and faith of their fathers and forefathers, which, they have asserted, had remained unaltered throughout the ages. Religious traditions, however, are dynamic by nature and fundamentalist groups, such as the Ultra-Orthodox, tend to be particularly active in re-designing their traditions so as to make them more insular and immune to outside influences. While opposing changes, Ultra-Orthodox leaders and groups have implemented huge changes in Jewish customs and standards of observance as well as in the relation between different groups of Jews. ${ }^{9}$ For example, the Ultra-Orthodox unwillingness to recognize more acculturated or accommodating rabbis as legitimate has brought the older concept of More de Atra, local rabbis as the authoritative halachic figures in their own territories, to an end. The dynamic nature of fundamentalism is also evident in the significant developments that have taken place as new generations of Ultra-Orthodox have come on the scene. As a generalization, the movement has become more strict and demanding throughout the nineteenth and twentieth centuries. The dynamic nature of the movement has been accompanied by huge inner diversity. While from the outside it might look like a homogeneous camp, it is in fact a large and diverse religious-cultural movement. ${ }^{10}$ Divisions have to do with the areas from which the Ultra-Orthodox have arrived from as well as between Hasidic and non-Hasidic forms of leadership, authority and worship. The camp is composed of numerous communities that share the basic cultural values and adhere to the same narratives on the course of Jewish history, yet differ in small

8 For similar attitudes among Christian fundamentalists, see Marsden 1982; Weber 1983.

$9 \quad$ Katz 1998.

10 Friedman 1991 
details of appearance and customs. There are also varying shades of separatism from the outside culture. These communal divisions often result in inner struggles, the building and dissolving of coalitions and public institutions and even verbal and physical skirmishes. For example, most Ultra-Orthodox Jews in Israel lend their support to political parties that represent their interests vis a vis the Israeli government. However, a minority group considers such political maneuvers to be in violation of the community's values and boycotts the elections. ${ }^{11}$

While positioning themselves in opposition to modernity and the general culture, the Ultra-Orthodox have chosen, especially since World War II, to live their lives in large cities. They have made extensive usage of modern technology and international transportation. This has allowed them to build global networks, and unite over common causes. Most Ultra-Orthodox Jews are of Eastern European origins, and many of them consider traditional Eastern European customs to represent normative Judaism. The separatist communities in Germany were more acculturated than the Ultra-Orthodox groups in Eastern Europe and encouraged their male members to obtain general education and professional training, alongside Jewish traditional schooling, a reality that made some Eastern European leaders treat them with suspicion. By the turn of the twentieth century, the Germans and Eastern Europeans cooperated in establishing political bodies that came to represent the conservative elements of Orthodox Judaism in the public and political spheres. By that time the Ultra-Orthodox were reacting strongly to the rise of the Zionist movement, and especially to its Orthodox wing, Hamizrahi. ${ }^{12}$ Leaders of Ultra-Orthodox communities, such as the Munkatcher Rebbe, Chaim Elazar Spira (1868-1937) and the Satmar Rebbe, Joel Teitelbaum (1887-1979) shared the conviction that the Jews were forbidden "La'alot Bahoma", to re-enter history as active agents. They therefore opposed the Zionist agenda vehemently, viewing it as a futile and dangerous attempt. The founding of an Ultra-Orthodox party, Agudat Israel, came to present a political alternative to Zionist voices. ${ }^{13}$ While inner divisions, such as between Hasidic Jews and "opponents", did not disappear, Eastern and Central European traditionalists were now willing to put aside some of their differences and cooperate in order to fight the modernists and strengthen the ideological and spiritual walls around their communities.

After World War I, Agudat-Israel became active in a number of Eastern European countries and in Palestine, expressing opposition to the Zionist movement in international forums. Still, in the mid-1920s, the Ultra-Orthodox party began, on a pragmatic basis, to cooperate with the Zionist establishment. Its leaders wished to get their share of certificates for immigration to Palestine as well as budgets and allocations of land. This created a backlash to the more radical

11 On Ultra-Orthodox life and institutions, see Heilman 2000.

12 Ravitzky 1996.

13 On Agudat Israel, see Bacon 1996. 
elements among the Ultra-Orthodox in Jerusalem. In 1937, Amram Blau (18941974) and others, established Neturei Karta, Defenders of the City, a group that in the 1950s-1960s galvanized Ultra-Orthodox antagonists of the newly created state and demonstrated in Jerusalem against the desecration of the Sabbath. ${ }^{14}$ This group gave voice to a minority within the Ultra-Orthodox. Most chose to operate within the system in order to protect their community's interests. Avraham Yishaya Karelitz (1878-1953), known as the Hazon Ish, emerged as a spiritual leader, giving voice to Ultra-Orthodoxy at large, in opposing the conscription of women as well as of yeshiva students.

The deferment from conscription, which the Israeli governments granted to its Ultra-Orthodox coalition partners, proved detrimental to the development of the community, which, since the 1950s, turned studies in yeshivot, rabbinical academies, previously a privilege of a small elite, into routine for all young men. While Zionist Orthodox also obtained some rabbinical studies, for the UltraOrthodox it has become a way of life. Men continue their studies after marriage, while their wives work for a living. ${ }^{15}$ As a rule, the Ultra-Orthodox remain in coalition with governments, whoever heads them, to ensure the continuation of this arrangement and the integrity of their communities.

Many observers thought, in the aftermath of the Holocaust, that Ultra-Orthodoxy would not be able to overcome the deadly blows that the Nazi death machine and the Communist regimes have dealt the traditionalist Jewish communities in Eastern Europe. However, to the amazement of many, including the Ultra-Orthodox themselves, the community has risen up, like a phoenix, from the ashes, showing signs of vitality and growth. Contrary to warnings, America, Israel and centers in Australia, Canada, England and Belgium, proved to be congenial to the reconstruction and thriving of Ultra-Orthodox communities. While previously traditionalist Jews, who settled in the New World, saw a need to acculturate quickly in order to accommodate successfully to their new environments, the post-Holocaust Ultra-Orthodox migrants saw matters differently. They wished to maintain many of their customs, including their distinctive attire, and built an independent educational infrastructure that has enhanced the community's ability to retain most of its children within the fold.

The separatist, seemingly archaic, character of Ultra-Orthodox societies brought sociologists and anthropologists, as well as journalists and writers, to take special interest in the various aspects of their lives. Some are fascinated by the arranged marriages that are the norm in the community, while renegade female writers, such as Yochi Brandeis or Judith Rotem, point to the sometimes difficult position of women, who are married of young, and who carry most of the burden of raising large families. Ultra-Orthodox women give birth to averagely five and a

14 Inbari 2016.

15 There is an extensive literature from the perspective of women on the division of labor in the Ultra-Orthodox community. 
half children in the United States and seven children in Israel, about three times more than liberal Jewish women in these countries. ${ }^{16}$ Especially in Israel, most Ultra-Orthodox live an economically frugal existence. In spite of an impressive network of mutual aid and extensive government support, many in community live in poverty, depriving themselves of the luxuries of western consumer societies. $^{17}$

Relationships between the Ultra-Orthodox community and the liberal segments of Israeli society have become strenuous. Many secular Jews resent the separatist nature of the Ultra-Orthodox community, and the refraining from economic activity of so many Ultra-Orthodox men. Likewise, the Ultra-Orthodox have not celebrated Israeli civil holidays and have not recited prayers for the safety and well-being of the state. The exempt from military service has been a huge source of contention in a country that has had ongoing conscription since its inception. ${ }^{18}$

Still, the community has been on the growth. In addition to a remarkable demographic growth, since the late 1960s, it received unexpected reinforcements from a post-modernist movement of return to tradition that has brought tens of thousands of young men and women to abandon open liberal societies and join the more conservative Ultra-Orthodox..$^{19}$ Rejecting much of the modernist worldview, which their grandparents' generation had embraced, the new adherents included artists, soldiers, former Kibbutz members, and children of the veteran Israeli elites and, in America, also academicians and professionals. The growing trend has boosted the morale of the Ultra-Orthodox. Here are liberal Jews turning their backs on the freedoms and opportunities embodied in the open, secular society, "coming back" into the fold. A number of Ultra-Orthodox groups and leaders decided to create venues of outreach in order to further enlarge the community's ranks. Their mode of evangelism is based on the understanding that becoming observant and joining Ultra-Orthodox life is a long process involving extensive studies. For that purpose they have created a large number of yeshivot for beginners, a novelty in Jewish life.

The growth of the Ultra-Orthodox community and the self-understanding of its members, who see themselves as representatives of the true and authentic tradition, has affected the more acculturated Zionist Orthodox. The trend since the 1960s has been towards more rigid observance and greater acceptance of UltraOrthodox norms. By the 1980s, Zionist Orthodox have attempted to combine both sets of values and standards. ${ }^{20}$ The Hardalim, Ultra-Orthodox Zionists,

16 For example, Rotem 1992.

17 See Daum / Rudovsky 1997.

18 On Israeli liberal resentment of Haredi society, see Ilan 2001.

19 Davidman 1993.

20 On the background to this trend, see Aran 1991. 
coupled Ultra-Orthodox norms of piety and observance with a messianic nationalist faith. Many in the Settlers movement have promoted this combination.

In the 1980s-2010s, the veteran, almost exclusively Ashkenazi, Ultra-Orthodox community, was both strengthened and challenged by a large movement of religious revival and return to the roots of Mizrahi Jews in Israel. Previously, most Jews from Middle-Eastern and North-African countries were mildly traditional, with only a minority choosing secular outlooks or adhering to Orthodox norms. The new movement changed that reality and brought tens of thousands of Mizrahi Jews to adopt both Ultra-Orthodox standards of piety and anti-modernist stands. ${ }^{21}$ The movement also promoted ethnic pride and the preservation of Mizrahi culture and tradition. It created parallel political, educational, rabbinical and welfare institutions similar to those of the veteran Ultra-Orthodox community and used its new political power to obtain extensive government support. ${ }^{22}$

The political influence of the Ultra-Orthodox has been on the rise in Israel. As a rule, the Ultra-Orthodox parties offer the government backing in matters that relate to security, foreign-policy, and the economy, in exchange for allowing them exemption from military service, cultural autonomy and financing for separate educational and housing systems. Ultra-Orthodox parties often became essential members of the coalition, and the budgets allocated for their community's educational and housing projects have grown considerably. Similar developments have taken place on the local level, such as in Jerusalem's municipal politics, where the Ultra-Orthodox have successfully demanded, in return for their support, to have their neighborhoods closed to traffic on the Sabbath and holidays. This has affected the character of Jerusalem, where many neighborhoods and schools have become Ultra-Orthodox. Outside of Israel, the Ultra-Orthodox as a rule do not run for offices, but lend their support to those candidates that respect their cultural separatism and educational autonomy. The Zionist Orthodox have been active on the political front.

\section{The Zionist Orthodox}

Zionist Orthodoxy has come on the scene a short while after the rise of political Zionism. The group represented a minority voice within both Jewish Orthodoxy and Zionism. Its proponents established HaMizrahi, a moderate political party that saw its mission in carving a niche for observant Jews who supported the Zionist agenda. HaPoel Hamizrahi, which combined Labor politics with a minimalist form of observance, became a larger political party, although the two parties united after the birth of the state of Israel.

21 Leon 2009.

22 On Mizrahi Ultra-Orthodox, see Lehmann / Siebzehner 2006. 
The Moderate stand on politics and piety came to an end after the June 1967 war. While many Jews reacted with joy to the Israeli victory, seeing in it a triumph of the Zionist project at large, for many in the Zionist Orthodox camp it signified a messianic development. Already during the war, the chief military rabbi who was known for his accommodating rulings, Shlomo Goren, appeared near the Wailing Wall blowing a shofar, ram's horn, as if to announce the beginning of messianic times. About a year after the war, a group of a few dozen Zionist Orthodox, headed by Rabbi Moshe Levinger, settled in Hebron, disregarding government regulations. In October 1974, this early attempt turned into a large movement, when thousands marched, and hundreds settled, in newly established posts in what had been the West Bank of Jordan, and for the Settlers has become Judea and Samaria. ${ }^{23}$ For the Orthodox enthusiasts, building their homes in these areas embodied a messianic purpose. They were taking steps towards the building of David's messianic kingdom. The Settlers adopted Rabbi Zvi Yehuda Kook as their spiritual leader and source of inspiration. The son of a chief rabbi and a mystic, Abraham Isaac Hacohen Kook, Zvi Yehuda took his father's teachings a few steps further. ${ }^{24}$ The Land of Israel has become a central component and a focal point of his and his disciples' theology.

The Settlers' movement received enormous boost with the rise of the Likud to power in 1977, moving from a handful of small shanty towns to nicely built neighborhoods subsidized by government funding. The Zionist Orthodox have mobilized politically to defend their settlements from possible restrictions that the Israeli government might impose and to ensure government support for the enlargement of the Settlements project. In spite of the Israeli withdrawal from Gaza, the Settlers' community has grown considerably, reaching hundreds of thousands of people. It has created its own subculture, complete with its own dress code, a mixture of countercultural attire and Ultra-Orthodox norms, and independent media ventures.

While the Settlers' community is highly devoted to Israel and its sons play a growing role in its military, members of the community have at times taken the law into their hands. In 1983, the Israeli security services discovered cells of underground militants among the Settlers that were stocking arms and ammunition in preparation for a possible clash with the Israeli state and its security forces, in case of an Israeli attempt to withdraw from the occupied territories and evacuate the settlements. ${ }^{25}$ There have also been at times incidents of violence directed against Palestinians, allegedly in retaliation against violence directed against Jews. These have included the destruction of trees, injuring mayors of Palestinian towns, and the burning of a Palestinian home that resulted in fatalities. While most Settlers

23 On the gradual up hazard building of a large infrastructure of settlements, see Gorenberg 2007.

24 Aran 1997.

25 Sprinzak 1991; Friedman 1992. 
have not resorted to underground activities or to sabotage or harassment of Palestinians, the Settlers' camp as a whole has stood on the radical side of the Israeli political and ideological spectrum and many have come to see it as a potential obstacle to a peace agreement and to an atmosphere of reconciliation between Arabs and Jews.

\section{Building the Temple}

Of special concern for Israeli security, as well as peace-hopefuls, in Israel and other countries, has been the possibility that messianically-oriented radical Jews or Christians might heart the Muslim mosques on the Temple Mount and bring about a regional doomsday. ${ }^{26}$ In order to appreciate this fear, one has to examine the role of the Temple and the Land of Israel in Jewish and Christian thought.

The Temple in Jerusalem had been a central institution in Israelite religion, as well as in the Judaism of the Second Temple period. For Jews of that period, the Temple served as the ultimate spiritual point on earth, a place where it was possible for them to atone for their sins and reconcile with God in a definite manner. Pilgrimages to the Temple in Jerusalem were considered essential rites. The Temple developed into a unifying symbol for a growingly diverse Jewish community around the Mediterranean world. The destruction of the Temple in 70 CE created therefore a serious vacuum in Jewish communal and spiritual life. Instead of a physical temple, rabbinical Judaism put its premium on sacred texts, and promoted a "temple in time", as the weekly Sabbath had become a holy day, similar in sanctity to a holy place. Jews purified themselves in honor of the Sabbath and entered the holy day in the same manner they would enter a holy place, cleaning their bodies, wearing special cloths, preparing festive meals, lighting candles and recite special prayers. Synagogues, "houses of gatherings" in Hebrew, came about during the Second Temple period, and developed, after the Temple's destruction, into houses of worship and learning, where Jews prayed and read sacred texts.

Still, Jews prayed to God to gather them back to Zion, rebuild Jerusalem, recreate the Temple and enable them to fully atone for their sins. The Temple came to symbolize redemption. Rabbis spent time on issues relating to the Temple, its measures, sacrificial system, and the alms and donations presented to it. Most rabbinical authorities throughout the Middle-Ages and Modern Era have viewed the Temple Mount as being as sacred as it was when the Temple was standing. ${ }^{27}$ The Mishnah, the post-Biblical compilation of lore and law, outlined the various degrees of sanctity of areas on the Temple Mount and the rituals of purification people needed to perform in order to enter these areas. Jews have

\footnotetext{
26 Ariel 2001.

27 Mishnah, Tractate Middot. Measures.
} 
been required to purify themselves with the ashes of a red heifer before entering the Mount, although there are no longer red heifers to be found. Rabbis have also feared that Jews might step on restricted sacred ground, such as the Holy of Holies, onto which ordinary Jews, and even ordinary priests, were not allowed to enter. Most Jews have accepted the rabbinical ban and saw entrance to the Temple Mount as taboo. However, Jews had not much to say about the manner in which the Temple Mount was governed. Between the destruction of the Temple in $70 \mathrm{CE}$ and 1967, the Temple Mount had been ruled by Pagans, Christians and Muslims. In the seventh and eighth century $\mathrm{CE}$, the new rulers of the city have turned the mountain into a sacred Muslim site, building a number of mosques and chapels. ${ }^{28}$

In June 1967, when Israel conquered East Jerusalem, including the Temple Mount, it symbolized to many Israelis an historical victory, the realization of an old dream. However, most Israelis did not wish to rebuild the Temple. By this time, the Temple Mount was a Muslim site, administered by a Muslim Waqf (religious endowment) and both secular and observant Jews had no interest anymore in building the Temple. The Israeli government proclaimed its wish to maintain the status quo antebellum on the Temple Mount as well as in other Muslim and Christian holy sites and the chief rabbis of that time, Yitzhak Nissim and Issar Unterman, declared that Jews were forbidden to enter the Temple Mount. In 1967, voices, such as that of Shlomo Goren, who wished to establish a synagogue on the Temple Mount, were in the minority. The mood in Israel changed after the war of 1973. Paradoxically, external threats to Israel's territorial gains, whether through war or peace negotiations, have inspired Jewish religious nationalists to take a proactive stand, including their determination to see the Temple rebuilt. ${ }^{29}$

Not all Settlers have been interested in the building of the Temple in an immediate way. Similarly, not all Jewish Temple Builders are Settlers. But the Temple Builders' movement has shared a great deal theologically, ideologically, and communally with the Settlers' movement. Since the 1980s, both movements have been part of Israel's Radical Right and currently many of the would-be Temple Builders live in settlements. Groups of Temple-Builders reinterpreted Jewish texts, putting greater emphasize on sacred space. Rejecting the understanding that the building of the Temple should be left for the Messiah to accomplish at the Fullness of Time, radical Zionist Orthodox thinkers have declared the traditional rabbinical ban on entering the Temple Mount to be erroneous.

The first organization of Temple-Builders was the Temple Mount and Land of Israel Faithful. Led by Gershon Solomon, a disabled IDF veteran and a lawyer, the Temple Mount Faithful gave voice at its inception, in the 1970s, to a large variety of Jews interested in the building of the Temple. Its periodic attempts to enter the Temple Mount, and organize prayers there, have enjoyed much media

28 On the Temple Mount, see Reiter 2001.

29 Inbari 2012. 
coverage. In the 1980s, Rabbi Joel Bin Nun, a leader of the now defunct Gush Emunim, the Settlers' major organization in the 1970s, established an institute for the halachic study of the building of the Temple. In a series of publications he pointed to what he considered to be the merits of the Temple and the sacrifices therein, which he believes would help reconcile God and humanity, and would therefore help bring about a messianic age. Other groups that formed during the 1980s-2010s, have included: Reshit-Yerushaliim, Jerusalem First, an Academy for studying Jerusalem and the Temple; Ha Tnuaa Lekinun ha Mikdash, the Movement for the Building of the Temple; Yeshivat Torat HaBayit, The Temple-Laws Yeshiva; El Har Adonai, Unto the Mountain of the Lord; Ha Tnuaa LeShihrur Har HaBayit, the Movement for the Liberation of the Temple Mount; and Yeshivat Ateret Cohanim, The Priest's Crown Yeshiva, to name just a few of the groups. $^{30}$

Jewish movements that have strived to build the Temple would not have carried their activities the way they did if it were not for evangelical Christians providing encouragement and assistance. Christian thinkers had traditionally seen the Temple as redundant after Jesus' sacrifice on the Cross, and interpreted the destruction of the Temple in $70 \mathrm{CE}$ as resulting from the Jewish unwillingness to acknowledge Jesus' role and mission. The idea that the Jews should go back to Palestine and rebuild Jerusalem and the Temple became predominant among Christian messianic groups, especially pietist and evangelical Protestants. After the 1967 war, evangelicals with messianic yearnings have come more than before to expect the building of the Temple at the end of the current era, in preparation for the return of the Messiah to earth. In such scenarios, it is often Antichrist, an imposter of the Messiah, who is expected to achieve global power that would initiate the building of the Temple. The Temple, or rather its rebuilding, seemed to evangelical Christians to be the one event standing between this era and the next.

In the late 1970s and the 1980s, premillennialist Christians and groups of nationalist-Orthodox Jews, who were interested in the building of the Temple, discovered each other. Such Christians have received reassurance for their messianic faith from Jews who were studying the Temple rituals, or manufacturing utensils to be used for sacrificial purposes according to biblical or Talmudic measures, or trying to breed a new brand of heifers. Similarly, Orthodox Jews received reassurances from Christian interest and support. Initially, Jewish proponents of the building of the Temple did not appreciate the Christian faith more than Christian messianic groups appreciated the intrinsic value of the Jewish faith, but they saw such details as being beside the point. The important thing for them has been the Christian willingness to support their work. ${ }^{31}$

Christian proponents of building the Temple have made efforts to discover the exact site of the Temple. Some have searched for the lost Ark of the Covenant,

\footnotetext{
30 Inbari 2009.

31 Ariel 2013, pp. 198-213.
} 
adding a touch of adventure and mystery to a potentially explosive topic. The search for the "Lost Ark" has inspired a number of novels and a movie based in part on a real life figure. Some premillennialist evangelicals have also searched for the ashes of the red heifer, which are necessary, according to the Jewish law, in order to allow Jews to enter the Temple Mount, while others have supported Jewish attempts at breeding red heifers or began breeding such heifers on their own.

Pat Robertson, the renowned leader of the 700 Club and a one-time presidential hopeful, offered his support and hospitality to Gershon Solomon. In August 1991, the 700 Club aired an interview with Solomon. Robertson described Solomon's group as struggling to gain the rightful place on the Temple Mount. "We will never have peace", Robertson declared, "until the Mount of the House of the Lord is restored." Solomon, for his part, described his mission as embodying the promise for a universal redemption. "It's not just a struggle for the Temple Mount, it's a struggle for the [...] redemption of the world", he declared.

Examination of the mutual enchantment between evangelical Christians and Orthodox Jews, such as Robertson and Solomon, shows mutual influences. Solomon, for example, claims to have divine revelations, not unlike those among evangelical charismatic Christians. Jewish would-be builders of the Temple have also changed their opinion on Christians, impressed by the keen Christian interest and support. ${ }^{32}$ Those Christians, they discovered, were more enthusiastic about the prospect of building the Temple than most Jews. The theology and message of people, such as Gershon Solomon, has come to include Christians as important participants in the divine drama of salvation. Resurfacing the traditional Jewish idea that since the days of Noah all of humanity is in covenant with God, Jewish radical thinkers of the Settlers camp are claiming that Christians too have to strive and make an effort towards the advancement of the messianic times.

In assessing the tensions embodied in the struggle for the Temple Mount, one needs to take into consideration not only the messianic fervor of Jews and Christians, but the strong feelings of the local Muslim community and the support and sympathy of Muslims worldwide. An adversarial symbiosis has developed at times between Muslims and the Jewish and Christian Temple Builders. The agenda of some Jewish and Christian groups, who wish to change the status quo on the Temple Mount, has served to fuel and enhance the Palestinian claims. Throughout the 1970s-2010s, the Temple Mount, or the Haram al Sharif as it is known to Muslims, became a symbol of national liberation for Palestinian Muslims and their regard for the Mount has become even more pronounced. Sovereignty over the Mount played a prominent part in the peace talks that took place between Palestinians and Israelis in the late 1990s, and Ariel Sharon's visit to the Temple Mount in September 2000 was the starting point of the Second Intifada. Protecting the Temple Mount mosques became a priority for the Israeli security

32 Ibid. 
services. Even symbolic attempts to claim the Temple Mount as a Jewish site have had explosive consequences. On Sukkot, the Feast of the Tabernacles, in October 1990, the Temple Mount Faithful planned to enter the Temple Mount, and this time to lay a corner stone for the future Temple. The police, however, refused to allow them entrance to the Temple Mount and they left the place. But Muslim worshipers on the Mount felt threatened, and threw rocks at Jewish worshipers at the Wailing Wall. The atmosphere became volatile, as Muslim demonstrators chased the small police unit out of the Mountain, and Israeli anti-riot police stormed the area a short while later. Dozens of demonstrators and police officers were killed or wounded. The possibility that acts inspired by groups holding to messianic hopes would bring about a mini-apocalypse therefore became a concern for those taking interest in the developments in the Middle East. Should the mosques be seriously damaged, all hell might break loose.

\section{Conclusion}

At first glance Ultra-Orthodoxy and Zionist-Orthodoxy are very different communities that hold to ideologies far removed from each other and subscribe to very different life styles. A closer look reveals, however, strong similarities between the world views, agendas and life decisions of the Ultra and Zionist Orthodox. Both groups relate with owe to the Jewish sacred texts as the foundation of their religious tradition. Both view the biblical narratives as the basis of what they consider to be the special relationship between God, the people of Israel, and the Land of Israel. Both communities are thoroughly messianic in their theologies and yearnings, directing their lives towards the arrival of the messianic times. The two groups have promoted different paths to achieve that goal. Since 1967, the Zionist Orthodox have become more nationalist and right wing than other segments of the Jewish population. However, while the Ultra-Orthodox have traditionally resented the politically pro-active expansionist Zionist agenda, they too see themselves as troopers in God's army, struggling, through prayers, studies and righteous lives to bring in the messianic age. A number of Ultra-Orthodox groups, most notably the Hasidic group Chabad, have also become engaged in outreach, wishing to bring more people to fulfill the commandments as a means of ushering in the messianic times. Within the Zionist Orthodox movement, the standards of daily observance and commitment to studying Talmudic texts have also grown considerably.

The differences in life decisions have also become narrower. The Zionist Orthodox have embraced modern science, incorporated liberal education alongside the study of sacred texts, and have allowed women a growing amount of traditional education. Zionist Orthodox women have abandoned, however, the more carefree attire and personal appearance in favor of full cover of their hair and body and while they study, obtain degrees, and build careers, they make a greater 
effort at pro-creation than their mothers have made, and in such a way help enlarge the community and ensure the continuity of the Jewish people. In that both groups have been successful. Their numbers and role within the Jewish community has been on the rise, altering the character and agendas of the Jewish people as a whole.

\section{References}

Aran, Gideon: "The Father, the Son and the Holy Land", in: Appleby, R. Scott (ed.): Spokesmen for the Despised: Fundamentalist Leaders of the Middle East. Chicago 1997.

Aran, Gideon: "Jewish Zionist Fundamentalism: Gush Emunim, the Bloc of the Faithful in Israel”, in: Marty, Martin E. / Appleby, R. Scott (eds.): Fundamentalisms Observed. Chicago 1991.

Ariel, Yaakov: An Unusual Relationship: Evangelical Christians and Jews. New York 2013.

Ariel, Yaakov: "Doomsday in Jerusalem? Christian Messianic Groups and the Rebuilding of the Temple", in: Terrorism and Political Violence (13/1) 2001, pp. 1-14.

Bacon, Gershon: The Politics of Tradition: Agudat Yisrael in Poland. Jerusalem 1996.

Breuer, Mordechai: Modernity within Tradition. New York 1992.

Davidman, Lynn: Tradition in a Rootless World: Women Turn to Orthodox Judaism. Berkley 1993.

Friedman, Menachem: The Haredi (Ultra-Orthodox) Society. Jerusalem 1991.

Friedman, Robert I.: Zealots for Zion: Inside Israel's West Bank Settlement Movement. New York 1992.

Gorenberg, Gershom: The Accidental Empire: Israel and the Birth of the Settlements, 1967-1977. London 2007.

Heilman, Samuel: Defenders of the Faith: Inside Ultra-Orthodox Jewry. Berkley 2000. Ilan, Shahar: Haredim LTD. Jerusalem 2001.

Inbari, Motti: Jewish Radical Ultra-Orthodoxy Confronts Modernity. New York 2016. Inbari, Motti: Messianic Religious Zionism Confronts Israeli Territorial Compromises. New York 2012.

Inbari, Motti: Jewish Fundamentalists and the Temple Mount. Albany 2009.

Katz, Jacob: A House Divided: Orthodoxy and Schism in Nineteenth Century Judaism. Waltham 1998.

Katz, Jacob: Out of the Ghetto: the Social Background of Jewish Emancipation. Syracuse 1973.

Kahana, Maoz: From the Noda BeYehuda to the Hatam Sofer: Halacha and Thought in Response to the Challenges of the Time. Jerusalem 2015.

Lehmann, David / Siebzehner, Batia: Remaking Israeli Judaism: the challenge of Shas. New York 2006.

Leon, Nissim: Gentle Ultra-Orthodoxy: Religious Renewal in Oriental Jewry in Israel. Jerusalem 2009. 
Marsden, George: Fundamentalism and American Culture: the Shaping of Twentieth Century Evangelicalism, 1870-1925. New York 1982.

Mayer, Michael: Response to Modernity: A History of the Reform Movement in Judaism. Detroit 1995.

Ravitzky, Aviezer: Messianism, Zionism, and Jewish Religious Radicalism. Chicago 1996.

Reiter, Yitzhak: Sovereignty of God and Men: Sanctity and Political Centrality on the Temple Mount. Jerusalem 2001.

Rotem, Judith: Distant Sister: the Women I Left Behind. Philadelphia 1992.

Silber, Michael: "The Invention of Ultra-Orthodoxy: the Emergence of a Tradition”, in: Wertheimer, Jack (ed.): The Uses of Tradition: Jewish Community in the Modern Era. New York 1992, pp. 23-82.

Sprinzak, Ehud: The Ascendance of Israel's Radical Right. New York 1991.

Weber, Timothy: Living in the Shadow of the Second Coming: American Premillennialism. Grand Rapids 1983.

\section{Documentary}

Daum, Menachem / Rudovsky, Oren: Life Apart: Hasidism in America. New York 1997. 